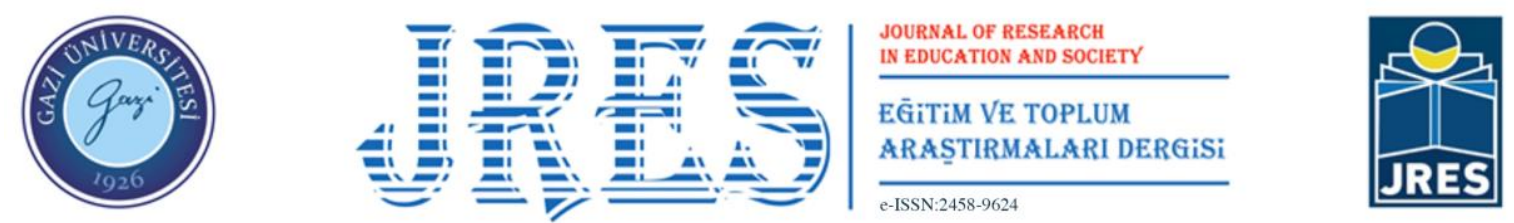

Volume: 8 Issue: 1 Page Range: 142-166 e-ISSN: 2458-9624 DOI: 10.51725/etad.894757

\title{
Making Sense of Teaching and Learning During the COVID 19 Pandemic: Studying Online at Home in Isolation
}

COVID 19 Salgını Sürecinde Öğretim ve Öğrenmeyi Anlamlandırma: Evde Karantinada Uzaktan Öğretim

\section{Mehmet Ali İçbay}

\begin{abstract}
This paper is about online education during the COVID 19 pandemic. More particularly, it is about exploring how university students make sense of their online teaching and learning practices during the COVID 19 pandemic. In order to discover their sense-making practices, this study investigates how a group of freshman students in a public university experience online education, focusing on their routine interactions with it. Between October 2020 and January 2021, the study collects the data from 165 freshman students. 133 participants take part in the first stage, describing their initial experiences with online education in a one-page note, in the second stage 25 participants talking about those experiences in semi-structured interviews, in the third stage 89 responding to the online survey, and 7 sending feedback for the draft report in the last stage. The data from those four sources are presented in four sections: (1) the participants' routines with online education, (2) the benefits and (3) the disadvantages of online education according to their online practices, and (4) the students' suggestions to improve the quality of online learning. A closer look on the findings suggests that the sudden massive transition to online education due to the COVID 19 outbreak results in both some advantages and some unforeseen undesirable consequences, one of which is the common confusion among the students that online education lacks socialization opportunities or unfair access to resources.
\end{abstract}

ÖZ
Bu çalışmanın konusu, COVID 19 salgını sürecinde üniversite öğrencilerinin uzaktan eğitim ile ilgili
deneyimleri ve görüşleridir. Dolayısıyla, bu araştırma COVID 19 salgınında üniversite öğrencilerinin
öğretim ve öğrenmelerini nasıl anlamlandırdıklarını ortaya koymayı hedeflemektedir. Bu
anlamlandırma sürecini meydana çıkarmak için, birinci sınıf üniversite öğrencilerinin uzaktan eğitim
ile deneyimleri irdelenmiş ve bu öğrencilerin uzaktan eğitim ile günlük etkileşimlerine odaklanılmıştır.
2020 Ekim ile Ocak 2021 döneminde 165 birinci sınıf üniversite öğrencilerinden veri toplanmıştır. Veri
toplama sürecinin ilk aşamasında 133 öğrenci uzaktan öğretim deneyimlerini bir sayfalık notla
açıklamıştır. İkinci aşamada 25 öğrenci yarı yapılandırılmıs görüşmelerde bu deneyimleri ayrıntılı
ortaya koymuştur. Üçüncü aşamada 89 öğrenci anket sorularına yanıt vermiş ve dördüncü aşamada 7
öğrenci araştırmanın taslak metnine geri dönüt sağlamıştır. Bu dört aşamadan elde edilen veriler dört
bölümde bulgular olarak sunulmuştur: (1) uzaktan eğitimile öğrencilerin günlük etkileşimi, (2) uzaktan
eğitimin artıları, (3) ekssileri ve (4) uzaktan eğitimi geliştirecek öneriler. Bu dört bölümdeki bulgulara
yakından bakınca, COVID 19 salgını nedeniyle yükseköğretimin ani ve devasa dijital dönüşümünün
bazı olumlu sonuç ve bazı öngörülmeyen ve arzu edilmeyen olumsuz sonuçlara neden olduğu öne
sürülmüştür. Bu olumsuzluklardan birisi de üniversite öğrencilerin yaşadı̆ğı uzaktan eğitimin
sosyalleşme olanaklarından ve kaynaklara eşit ulaşımdan mahrum olduğundan kaynaklı kavram
kargaşasıdır.

ÖZ

Bu çalışmanın konusu, COVID 19 salgını sürecinde üniversite öğrencilerinin uzaktan eğitim ile ilgili deneyimleri ve görüşleridir. Dolayısıyla, bu araştırma COVID 19 salgınında üniversite öğrencilerinin ogretim ve ogrenmelerini nasıl anlamlandırdıklarını ortaya koymayı hedeflemektedir. Bu anlamlandırma sürecini meydana çıkarmak için, birinci sınıf üniversite öğrencilerinin uzaktan eğitim 2020 Ekim ile Ocak 2021 döneminde 165 birinci sınıf üniversite öğrencilerinden veri toplanmıştır. Veri toplama sürecinin ilk aşamasında 133 öğrenci uzaktan öğretim deneyimlerini bir sayfalık notla açıklamıştır. İkinci aşamada 25 öğrenci yarı yapılandırılmış görüşmelerde bu deneyimleri ayrıntılı ortaya koymuştur. Üçüncü aşamada 89 öğrenci anket sorularına yanıt vermiş ve dördüncü aşamada 7 öğrenci araştırmanın taslak metnine geri dönüt sağlamıştır. Bu dört aşamadan elde edilen veriler dört bölümde bulgular olarak sunulmuştur: (1) uzaktan eğitim ile öğrencilerin günlük etkileşimi, (2) uzaktan eğitimin artıları, (3) eksileri ve (4) uzaktan eğitimi geliştirecek öneriler. Bu dört bölümdeki bulgulara yakından bakınca, COVID 19 salgını nedeniyle yükseköğretimin ani ve devasa dijital dönüşümünün bazı olumlu sonuç ve bazı öngörülmeyen ve arzu edilmeyen olumsuz sonuçlara neden olduğu öne sosyalleşme olanaklarından ve kaynaklara eşit ulaşımdan mahrum olduğundan kaynaklı kavram kargaşasıdır.
Author Information Mehmet Ali İçbay (D)

Assoc. Prof. Dr., Çanakkale Onsekiz Mart University, Çanakkale, Turkey icbay@comu.edu.tr
Keywords

Online education COVID-19

Pandemic in Turkey

Online ethnography

Anahtar Kelimeler

Uzaktan öğretim

COVID-19

Türkiye'de salgın

Dijital etnografi

Article History

Arrival: 10/03/2021

Editing: 14/05/2021

Acceptance: 19/05/2021

For Attribution: İçbay, M.A. (2021). Making sense of teaching and learning during the COVID 19 pandemic: Studying online at home in isolation. JRES, 8(1), 142-166. https://doi.org/10.51725/etad.894757 


\section{Introduction}

A novel coronavirus, formally named as SARS-CoV-2 but widely known as COVID-19, broke out in Wuhan, China in late December 2019 (Wang, Horby, Hayden \& Gao, 2020, p. 470). Approximately in two months, this local outbreak evolved into a global pandemic, leading the novel coronavirus to spread rapidly in all continents (McAleer, 2020, p. 46). In order to prevent the spread, local and national authorities in many countries began taking several measures, including social distancing, self-isolation, working at home, and closing large gathering settings like restaurants, gyms, museums, libraries, theatres and schools (Bedford et al., 2020, p. 1016). Higher education institutions, as a form of large gathering site, first extended their semester breaks or created a hybrid learning environment for their students, but when the coronavirus cases increased exponentially, most closed their campuses and moved to online instruction completely (Crawford et al., 2020, p. 19). Following those precautions, the Council of Higher Education, the national authority regulating the tertiary education in Turkey, first took a short break for traditional face-to-face teaching in the universities in early March 2020, and two weeks later ordered that all higher education institutions in Turkey must close their campuses and move to online instruction (Erkut, 2020, p. 127). And since then, the higher education students in Turkey have been attending their classes online at their homes, in isolation, and in quarantine (for more than a year as of May 2021).

This paper is about this sudden transition to online education. More particularly, it is about exploring how university students make sense of their online teaching and learning activities during the coronavirus pandemic. In order to discover their sense-making practices, the study investigates how the students experience online education, focusing on their routine interactions with it. The key theoretical principle framing this research assumes that the participants' self-reports can provide accounts for their sense-making practices, offering insight into their conceptualization of online education. Following this assumption, the participants are initially asked to describe their routine participation with online education, and then express their opinions about it. This paper here reports these accounts that uncover and provide descriptions of how university students make sense of their online teaching and learning activities during the coronavirus outbreak.

Online education (also known as online learning, e-learning, remote teaching, web-based education, or online instruction) is a category of third-generation distance education. It is defined as a form of distance "education being delivered in an online environment through the use of the internet for teaching and learning" (Singh \& Thurman, 2019, p. 302). As a result, it is frequently characterized by two-way communication media "that enable interaction between the teacher who originates the instruction and the remote student" (Bates, 2005, p. 7), and by the synchronous (or asynchronous) virtual environment where students can modify their learning activities according to their needs and specific conditions. Due to these characteristics, online education is easily accessible, relatively cheaper, offers richer experiences to a more diverse student population, and provides more flexibility to those students than the traditional face-to-face education (Dwahan, 2020, p. 6).

Online education has developed tremendously due to the rapid expansion of the internet. It has, consequently, become an integral and inescapable part of higher education (Kebritchi, Lipschuetz \& Santiague, 2017, p. 5). Not only has it made teaching and learning more flexible, more accessible, and more affordable, but it has also allowed educational institutions to create, store, access and interact instructional materials online, fast, and efficiently (Bates, 2005, p. 7). Due to those advantages, many higher education institutions have gradually moved their instructional activities online (Zimmerman, 
2020). However, when the coronavirus broke out in early 2020, and when the national and local authorities ordered the higher education institutions to "switch, almost overnight, to online teaching" (Daniel, 2020, p. 91), the speed of moving instruction online became "unprecedented and staggering" (Hodges, Moore, Lockee, Trust \& Bond, 2020, p. 2). And, this sudden shift to online education resulted in unforeseen challenges, "the main ones being access to technical infrastructure, competences and pedagogies for distance learning and the requirements of specific fields of study" (Marinoni, van't Land \& Jensen, 2020, p. 11). For example, around 8 million students at 202 higher education institutions in Turkey were required to moved online in a short period, two weeks, in March 2020, leaving half of those students without internet connection, and one third of them without any computer or tablet to make use of online education (Karadağ \& Yücel, 2020, p. 190).

This study finds its main interest in how this massive sudden shift is experienced by the university students. It explores how the students make sense of this shift in such a short time, focusing on the changes in their learning routines. Also, the study aims to identify how the coronavirus outbreak plays a role in this sense-making process. The paper first explains how the descriptive work reported in this paper is structured, providing a summary of methodology, then lists the findings from the students' reports in four headings. It ends with the discussion of these findings, emphasizing the confusion that the students have developed about online education due to the coronavirus outbreak.

\section{Method}

This study is a qualitative ethnographic work. It studies college students in their online settings and their routine interactions with it, paying attention to how they make sense of their online learning practices. More particularly, it aims to develop an understanding of online teaching and learning in all their complexities, discovering what meanings the university students make of online education while they engage their instructional life in a virtual environment (see Anderson-Levitt, 2006, pp. 279-282). Following this primary goal, this study offers a thorough and in-depth descriptive analysis of how online education is experienced by the university students during the coronavirus quarantine.

This study can be also considered as an online ethnographic work (also known as virtual ethnography, netnography, cyberanthropology, or digital ethnography). Online ethnography explores cultures and communities gathering data using internet technology (Marshall \& Rossman, 2011, p. 183). When compared to traditional ethnography, online ethnography has some advantages, including being less obtrusive, less costly, more accessible, and more convenient (Kozinets, 2010, p. 56). The disadvantages, however, include "higher risks of misrepresentation, difficulties to interpret noncontextualized data in an impoverished social context and the complexity of ethical considerations" (see Tunçalp \& Le, 2014, p. 60 for a review on online ethnography). There are two reasons for considering this study as an online ethnography. Firstly, the field in the study is located online. The field in this study is a virtual environment, online education during the coronavirus pandemic, and the participants engage with their routine learning practices in this virtual setting. Secondly, the data for this study is gathered using internet technology. The university students' notes, the interviews, the survey, and the feedback in the member-check stage are all collected using the internet tools.

The participants in this study are 165 college students in their freshman years attending teaching programs in the Faculty of Education at Çanakkale Onsekiz Mart University, Turkey. The firstyear students are attending the Departments of English Language Teaching, Japanese Language Teaching and Chemistry Teaching in the Faculty of Education. They are also the researcher's freshman students attending his course, Sociology of Education, in the Fall 2020 semester. Out of 165 students, 
however, 133 participants take part in the first stage of data collection, 25 in the second stage, 89 in the third stage, and 7 in the last stage. According to the survey data gathered in the third stage, the majority are aged between 18 and 21, two participants aged 23, 24 and 38. There are 60 female and 29 male students. Most live in a big city, 7 in a small town, and 8 in a rural place. Their average weekly load is 8 online courses (approximately 16 hours a week). The convenience sampling strategy is used (Miles \& Huberman, 1994, p. 28) because the participants are the researcher's freshman students attending his course, Sociology of Education, in Fall 2020 semester.

There are four data collection stages in this study. In the first stage, the participants are asked to write their initial experiences with online education (see Appendix A for the instruction). On around one-page paper, they are required to describe their experiences with online education and express their opinions about the advantages and disadvantages of online education. A few also provide some suggestions to improve online education. 133 participants submit their notes in late October 2020 using the assignment section on Microsoft Teams program. In the second stage, the researcher conducts semiconstructed interviews with 25 volunteered students in early November 2020. Using Zoom, a videotelephony software program, the participants talk about their experiences, their opinions about the use of online education during the coronavirus, and their suggestions to improve it (see Appendix $\mathrm{B}$ for the questions asked in the interviews). At the end of the interviews, there are 442 minutes of interview, an average of 18 minutes, ranging from 32 to 10 minutes. The third stage in the data collection is the online survey. The 16 items in the survey are based on the preliminary findings from the first and second stages. The seven items ask the participants to provide long answers while 9 items focus on the details about their experience. In late November 2020, 89 participants answer the survey, supplying detailed information about their experiences and opinions about online education (see Appendix $\mathrm{C}$ ). The final stage is the member-check. The feedback in the member check stage is thought to allow the participants "to verify that the findings reflect the participants' intended meanings" (see Kornbluh, 2015, p. 397). The participants are asked to provide comments for the draft findings shared by the researcher. 7 participants send their feedback using Microsoft Teams and 2 using WhatsApp in early January 2021 (see Table 1 for the data collection stages).

Table 1. Data Collection Stages

\begin{tabular}{lccc}
\hline Stage & Type & Date & Participant Number \\
\hline Stage 1 (1R) & Notes & Oct 2020 & 133 \\
Stage 2 (2R) & Interviews & Nov 2020 & 25 \\
Stage 3 (3R) & Survey & Nov 2020 & 89 \\
Stage 4 (4R) & Member-check & Jan 2021 & 9 \\
\hline
\end{tabular}

The data analysis in this study starts with organizing the data from the notes, interviews, and survey. This preliminary stage helps the researcher perform minor editing, clean up huge piles of data, and thus turn them into the manageable and analysable chunks. It is the first step in the "process of bringing meaning to raw, inexpressive data" (Marshall \& Rossman, 2011, p. 210). In this step, I clean up some notes from the participants because they are not relevant to the research, eliminate two interviews due to the technical problems during the recording, and create the log for each data collection stage. This stage is followed by coding the data. I pick some actual words and phrases from the participants' sentences to represent their experiences and perspectives. Those codes cluster together and create themes as the coding process continues. Meanwhile, I write some thematic notes, describing how those codes cluster as themes and how deviant cases might be interpreted as alternative themes (Marshall \& 
Rossman, 2011, p. 213). The last stage in the data analysis is about offering interpretations. Interpretation in this stage is meant to bring meaning and coherence to the codes and themes and to create an engaging story for the readers (see Patton, 2002, p. 480).

It is also important to note that the data reduction and interpretation processes in this study are not linear practices. I start these processes with some initial codes from the participant notes and with some thematic notes explaining how I have selected and clustered them. When I begin reading the interview transcripts, I modify those codes, removing some, adding a few, creating new themes, and offering new thematic notes. Toward to the end of this stage, I start writing the draft report, asking some of the participants to read it. Their feedback and the data from the survey help me organize the codes and themes, providing more insight into how the coronavirus outbreak and online education can be discussed as two related concepts.

\section{Ethical Statement}

This study was approved by the Ethics Board at Çanakkale Onsekiz Mart University on December 4, 2020 with approval number 06/16.

\section{Findings}

The data collection in this study starts in late October 2020, one month after Fall 2020 semester starts, by collecting the students' notes on their initial experiences with online education. It ends with their feedback on the draft report in January 2021, a week after their final examinations. During this four-month data collection period, the data collection and analysis center on two key questions: How do the students exprerience online education during the coronavirus outbreak? And, how do they view online education, comparing it with traditional face-to-face education? Thus, the findings here report their experiences with online education, focusing on how the students make sense of their online teaching and learning activities at home, in isolation, and in quarantine.

The following findings, gathered from the analyses on the interview transcripts, survey items, and document notes, are organized in four sections. The first section gives an insight into how the students interact with online education, including their routines and their initial observations about their interaction with online education. The next section lists the benefits of online education from the participants' point of view, emphasizing how online education provides safety and comfort in the coronavirus outbreak. The third section outlines the problems with online education according to their remarks, some of which are rooted in the pandemic, some rooted in the lack of infrastructure, and some rooted in the sudden transition to online instruction. The final section gives a summary of the suggestions offered by the participants to improve online education.

\section{Preliminaries}

One of the striking findings from the participant notes uncovers a surprising fact that it is the coronavirus outbreak that introduces online education to many students and provides them the first series of opportunities to experience the virtual learning. To put in another wat, the participants have not engaged in any online learning activity before March 2020. Thus, in order to explore how they become familiar with online education in such a short time, I ask the students about their online learning routines, focusing on the archaeology and characteristics of their experience with online education.

The participants' answers to the first three questions in the online survey show that most of the students have been attending online education for around six months, a duration of two semesters, 
when the survey is administered in November 2020. For 12 students, it is their first semester with online education, having spent around 3 months. Their responses also point that 42 students have had a previous experience with online education before the university. Due to the pandemic, 15 students study online in the high school, and 27 have an online learning experience while they get prepared for the university entrance examinations (see Salturk \& Gungor, 2020, p. 144 for similar results). Because the participants are mostly in their freshman year (only 3 sophomores), they have attended their two semesters online either in the preparatory classes, or in the first semester classes, or the last semester of high school, or in the last months of university preparation classes. When asked about their location, the participants state that most are living in a big city, 7 in a small town, and 8 in a rural place. Also, they report that 65 students have their own rooms to attend online classes, 36 using a shared place like living room, 8 outdoor places like a park or café, and one using a neighbour's house for connection.

The second group of questions in the survey focus on the basic characteristics of information technology that the participants use for online education. Their responses demonstrate that the majority use their smart phones and personal computers, and a few (6 students) use their tablets, to get connected. The students' answers in this study also indicate that the most frequently used online education program is Microsoft Teams due to the university policy. However, some use other programs as well such as Zoom, Google Meet, YouTube, Skype, Blackboard, EBA (Eğitim Bilişim Ağı - the educational network founded and maintained by Ministry of National Education in Turkey), and UBYS (Üniversite Bilgi Yönetim Sistemi - the information management system used by Çanakkale Onsekiz Mart University). When they are asked about the communication methods, the students say that they keep in touch with their classmates using smart phone messaging applications, mainly WhatsApp, Instagram, Telegram, and Discord, and that they contact their instructors using the chat section on Microsoft Teams, or emailing them, or in rare cases sending messages on WhatsApp. In addition, when they compare other programs, some of the participants in the interviews tell that they are highly satisfied with Microsoft Teams because it can provide the instructors and students to share slides, texts, video-recordings, and presentations, and can allow them to see and interact with each other during an online lesson.

The questions in the last part of the survey explore the students' online education routines, concentrating on how the instructors and students are accomplishing online lessons. According to their responses, most of the instructors either use the slides to present the lesson content or read aloud the lesson content using their cameras. Also, the students point that there are a few instructors who only read aloud the text without providing any visual materials or turning on their cameras. Unlike those teachers, there are some teachers who are using virtual or physical blackboards in their classrooms and answering the student questions on the board. Some of them share videos with their students, some provide reading lists, and some hold frequent question and answer sessions during their online lessons. When they are asked about how they solve problems when they have a problem online, the students state that they usually seek help from their classmates, sending messages on their smart phones, or try to fix those problems by switching to mobile connection, or restarting their computers or phones. Finally, the participant remarks in the interviews also suggest that the most frequently faced problems on virtual lessons are the internet speed, the freezing computers, and the software not responding due to the slow internet connection. 


\section{Online Education: Advantages}

Now I understand that learning can take place anywhere, independent of any place. Kemal $^{1}$ (Participant 3R03)

I think the most important plus is time. Because we don't have to go to the school, we can make most of the time we spend at the school. - Levent (Participant 3R34)

We are not away from our families. One can work better at their own home. - Bülent (Participant 3R16)

These quotes by the participants partly reflect their opinions about the advantages of online education. Some students, for example, think that online education provides the learning flexibility, studying comfortably at home. Some belive that it saves them from getting contaminated with or spreading the coronavirus. Some even tell that it creates a freedom of learning in pyjamas. This section in the paper presents the advantages of online education from the students' perspectives. It discusses those advantages in three parts: Online education provides (1) safety at home, (2) home comfort, and (3) time for personal growth.

\section{Safety at Home}

According to the students' remarks, the most significant advantage of online education is that online education keeps them safe from the coronavirus and prevents them from spreading it to others. The majority, aware of the outbreak risk, realize that self-isolation by staying at home and attending online lessons during the quarantine minimize the virus spread in the society. Nilgün (Participant 1R61), for example, is grateful that she is not staying in "a governmental dormitory with other 2000 girls" during the pandemic. Online education, for her, creates an opportunity to continue her studies at home and to be safe at the same time. Similarly, the findings in the study by Özdoğan and Berkant (2020, p. 23) support this argument, report that one of the benefits of online education is that it minimizes the risk of coronavirus spread and keeps them safe from the virus.

The participants in this study also know that college students are not among risk groups yet one of the major virus transmitters (see Yuki, Fujiogi \& Koutsogiannaki, 2020). Agreeing with this finding, Zeynep (Participant 1R29) argues that online education "helps prevent the outbreak spread by staying at home." Kerem (Participant 1R87) also supports this argument by suggesting the following:

Let me talk about the good part of online education firstly. We don't know who will survive during this pandemic. If I get infected, perhaps, I can die as well. My parents too. But, they have more risk. As a result, every day that we spend with them is very precious. At least, if they get infected, we will be next to them. And, this is very important.

\section{Comfort at Home}

Secondly, for many participants, online education provides a learning environment in home comfort. In other words, for many students in the study, online education offers an unfamiliar yet flexible and comfortable learning environment. This includes, for example, the freedom to attend online

\footnotetext{
${ }^{1}$ To keep the participant anonymity, their names are changed with the most commonly used names in 2019 in Turkey (see Turkish Statistical Institute, 2020) and with the names of my relatives. The first (Number $+\mathrm{R}$ ) in each quotation refers to the data collection stage, and the second number refers to the number assigned for each participant. 3R16, for example, is Participant 16 in the survey stage.
} 
classes in pyjamas, or in bed, or while having breakfast, or even while knitting, or polishing nails, or even doing manicure. Serkan (Participant 3R45) summarizes this freedom as follows:

I think the best part [of online education] is the availability of classes, very easy to reach them within the available limits. If you don't have any problem with the internet or the instruments, there is no worry for not attending the classes or for being late. You can attend the classes without having breakfast, without changing your clothes, or even without washing your face.

This advantage is supported with the study by Young and Norgard (2006, p. 113). According to the findings in their study, online education is a convenient option for the students due to their family and work obligations. A similar advantage is also reported in the study by Altun-Ekiz (2020, p. 7). A participant in her study tells that that the first thing that came to his mind [about the advantage of online education] is that he can listen to the online course while laying in his bed.

In addition to this freedom, the majority told that due to the flexibility characteristic of online education, they do not have to worry about transportation and accommodation as they do normally in traditional face-to-face education. That is, because online education is one-click away and provides home comfort, the participants do not spend time or money for transportation (paying for taxi or waiting for bus for example), or for accommodation (paying for rent or preparing breakfast in the morning for example). Hence, Füsun (Participant 3R41) can "have money in [her] pocket now." Swan et al. (2000, p. 365) find a similar finding in their study, stating that the students prefer online courses because of the distance that they have to travel for traditional courses.

Another advantage is self-control. For the participants, online education provides the learning independence, making them in charge of their own learning. They can, for example, adjust the learning speed according to their needs and preferences. Masal (Participant 2R03) tells that watching the recorded lessons in the evening help her understand the concepts more efficiently (see Yolcu, 2020, p. 244 for a similar finding). Similarly, for İbrahim (Participant 3R11),

It is a plus to attend the classes while sitting [at home]. The other point that I enjoy is that the lessons are video recorded. Sometimes I can miss the classes and I can watch the recordings for those classes later.

This finding is similar to the benefit, accessibility, reported in the study by Coyner and McCann (2004, p. 224). For them, online education provides the students to gain to information any time seven days a week. Because of the availability of information, students can study in any location at any time of the day according to their schedule (Li \& Irby, 2008).

\section{Time for Personal Growth}

Some of the participants in the study mention an unforeseen benefit of online education. According to their remarks, online education lets them focus on their personal improvement. Because they spend less (or no) time for the regular routines in traditional face-to-face instruction like traveling to the school or maintaining household, they can spare more time for personal development. Some participants find more time for their hobbies like windsurfing and skating. Kazım (Participant 3R82), for example, "started learning a new language." Sevgi (Participant 3R16) also begin exploring online certificates:

Because there is no spatial and temporal limitation [in online education], you can receive certificates from the universities abroad. 


\section{Online Education: Problems}

I have never enjoyed online education, even for a little bit. Of course, there were problems, hurdles in face-to-face education. But now, I want them [those problems] back! - Sude (Participant 1R15)

I think this online education sure makes students lazy. - Masal (Participant 2R03)

These quotes above are some examples for the problems that the participants experience when they are attending online education. Some of those problems are rooted in the inevitable consequences of coronavirus outbreak. The students have no other option but to follow their lessons online due to the coronavirus quarantine. Some problems are originated in the characteristics of online education. For the participants, online education lacks an authentic classroom setting, for example. Some can be attributed to the infrastructure. Most participants complain about the frequent internet cuts. And, some problems can be associated with the learners attitude towards online education. They, for instance, use their personal computers only for communication and entertainment purposes previously, and using them for education creates a dilemma for them. This section presents those problems in five parts: (1) problems at home, (2) technical problems, (3) problems with digital literacy, (4) lack of interaction, and (5) problems with online examinations.

\section{Problems at Home}

In order to decrease the spread of coronavirus, in March 2020 the university students in Turkey are asked to leave their campus, stay indoors, and attend their classes online during the pandemic. Most of them are left with no choice but to leave their dormitories, rooms, or houses, to quit their part-time jobs, projects, or trainings, and to live with their parents, siblings, or relatives, in isolation for an indefinite period. Meanwhile, they are also asked to continue their undergraduate programs online. This sudden transition from the traditional face-to-face instruction in the classrooms to the online instruction at homes causes a huge problem: Most houses lack the resources necessary to provide for the students and support their online education experiences.

For many students, sharing home with family members while studying online is a source of distraction. The routines at home such as repairing, vacuuming, or even regular conversations among family members cause distraction. Yiğit (Participant 1R04) lists those problems:

I can tell that this [online education] is not proper at home. For example, guests can come, or my father can make repairs at home, or my mother can vacuum and many other examples. These are tiny but critical hurdles that we are faced during this period.

In addition, sharing the limited resources at home is another source of trouble for online education. For some participants, sharing a room with brothers and sisters, who are also attending online classes, makes it difficult for them to focus on their virtual learning activities. There are, for example, "four male brothers at home" in Çınar's family (Participant 1R120). He is the oldest one, and they are all trying to follow their own online courses at the same time in the same room. In order to overcome this problem, Kumsal (Participant 1R08) decides to study in the evenings:

Because I do not have a room for myself in my parents' house, and also the internet is better at nights, I usually study in the evenings. 
Or, the participants ask their parents to provide them a convenient place for online education. Pelin (Participant 2R01), for instance, wants her parents not to stay in the living room when she is studying:

To tell the truth, there is almost no [connection] signal in my room. So, I have to stay in the living room [during online education]. And, I have to kick out my parents.

\section{Technical Problems}

One of the most frequently expressed problems in the participants' notes and interviews is the technical troubles. For them, there is lack of infrastructure, making it difficult, in some cases almost impossible, to access to online education. The problems in this part are organized in three levels: the internet service, the equipment (hardware), and the programs (software).

Most of the participants in this study complain about the quality of internet service in Turkey. Since they started attending online education in March 2020, almost all have experienced a problem with their internet service providers. Either the connection is too slow, or in poor quality, or unstable (a fluctuating connection speed), or too expensive to afford. Some students living in rural areas, for example, have no connection during stormy days. Or, due to the frequent power cuts, some are left with no choice but to use their mobile connections (see Kürtüncü \& Kurt, 2020, p. 72). Or, because they cannot afford connection at their homes, a few spend hours to find a Wi-Fi spot. One, for instance, has to use her neighbour's connection, or the other two students have to wait for a couple of weeks for the connection infrastructure to be installed in their neighbourhood and then to be connected to their houses.

The following three cases demonstrate how the lack of a steady internet connection can harm online education. The first case is taken from Miraç's (Participant 1R87) note. While he is explaining his view on the limitations of online education, he talks about his experience with online education:

Due to the connection problems, the videos [in online instruction] often disappear, I sometimes have to leave the [online] lessons, and the sound [in classes] deteriorates or disappears completely, to name a few.

Yusuf's (Participant 1R119) case is similar to Miraç's experience:

Technical problems like connection cuts can harm [online] lessons. For example, one day when the connection was poor, I had to reconnect. This caused me to miss some parts of the [online] lesson and distract my attention.

While she is expressing her opinion about the lack of universal policies for providing educational opportunities for all students during the coronavirus outbreak in Turkey, Defne (Participant 1R03) complaines about using her friend's resources:

For online education to be perfect, the resources and the level of education in the country are supposed to be high, and the quality of the education outstanding. In this process that we have been experiencing, I observe that people have been forced hard. In this difficult period that we live, I realize that the policies are not sufficient or proper. I am writing this [the note] at my friend's place using his computer and his internet connection, for example.

In addition to the infrastructure problems with the students' internet services, the students also observe that the campus connection that the instructors use for their online classes can cause serious 
problems. Eymen (Participant 1R84), for example, notices that "some problems with online instruction can happen due to the instructors' slow connection speed." Some of those problems results in "frozen" connections, and the poor video and audio quality, making the students restart the applications and programs on their computers.

Some of the technical problems result from the hardware (the equipment) and software (the programs and applications) that the participants use to get connected to online education. Most of the students in this study mainly use their smart phones, some their laptops, and a few their tablets or desktops. Also, there are some students who are using personal computers and smart phones simultaneously. The majority use Microsoft Teams, the communication platform, developed by Microsoft, that offers workspace, chat, videoconferencing, file storage, and application integration among the instructors and students. Some also make use of Zoom, and a few students using Google Meet, YouTube, Blackboard, Google Classroom, Skype and EBA (Eğitim Bilişim Ağ - the educational network founded and maintained by Ministry of National Education in Turkey) for their online classes.

The technical problem is chiefly caused by the inconsistency between the equipment that the students own and the program, Microsoft Teams, that requires for efficient running. In other words, either the participants' personal computers are outdated, need to be replaced or updated, or in some cases are broken, need to be repaired. Or, because most use their smart phones for online education or old computers, Microsoft Teams does not support some features and thus causes major problems on their smart phones and old computers. A good illustration is Azra's (Participant 1R119) experience with her old computer:

I already told that my computer was broken, and did not work as efficiently as previously, and did work too slowly. Today, it did not turn on, and because it was too slow, because it took a lot of time to start, I missed the morning class at 9. I could only catch the half of class.

Mustafa (Participant 1R35) expresses his experience with his old computer:

Because I don't have a new computer, I don't see what my instructors and classmates write in the chat section and sometimes miss what is being discussed there. Sometimes my computer freezes and what is being talked in that period passes in a second and words gets mixed.

Sena (2R02) has a similar experience with her old computer:

Sometimes when there is a problem with computer, it kicks me out. Until I get connected again, the topic is already discussed [...] and I can't join in the discussion when I want.

\section{Problems with Digital Literacy}

The sudden transition to online education due to the coronavirus outbreak has unearthed a deficiency, the lack of digital literacy, among the instructors and students in the higher education institutions (see Hodges et al., 2020, p. 2). The magnitude of the deficiency is too overwhelming for those parties because the transition is exceptionally sudden due to the outbreak. In this sudden unforeseen process, the digital transformation uncovers the fact that some instructors and students do not have previous experience with information technology, some have limited competence with online teaching and learning, and few have even developed negative attitudes towards the use of digital technologies for their teaching and learning activities (see Kurnaz \& Serçemeli, 2020, p. 275, for a similar finding). 
Surveying what 101 instructors, who teach the accounting courses in the universities, think about online education, they find that most of them are not comfortable with continuing online education after the pandemic.

The participants in the interviews particularly complain that most of their instructors have very limited experience with the use of information technologies for their courses. While she is describing her experience with online education, Pelin (Participant 2R01) tells that "no one, only the teacher, talked during the class, and he did not ask any question to anyone." A similar comment by Masal (Participant 2R03) supports Pelin's case:

For example, there is one lesson. I don't want to give away his name. Our teacher neither turns on his camera nor shares his screen. He sends us a text in pdf format. Then, during the class, he just reads that text.

The lack of digital literacy is found in the study by Eroğlu and Kalaycı (2020, p. 1014). According to the student responses in their study, online instructors do not make use of instructional materials other than texts in pdf.

\section{Self-Motivation}

In addition to the lack of proficiency in digital literacy among the instructors and students in the higher education, most of the participants in the study report that they have a serious trouble in maintaining their attention in the virtual classes. According to many, although online courses provide flexibility and autonomy for them, learning in home comfort and reaching instructional materials quickly can cause them to lose attention easily. Some associate the reason with the distractors at home, some with their computer habits, and some with their learning styles. For them, there are many distractors in their rooms, at their homes, in their desks, and on their computers, or smart phones.

Some participants observe that studying at home distracts their attention. For them, there are many distractors preventing them from focusing on their online lessons. Those distractors, for example, include food in the kitchen, television in the living room, or bed in their rooms. Eylül (Participant 1R22) explains how she loses attention during the online instruction:

When my computer, connected to the internet, is available in front of me at home in Izmir, it has become difficult to find the motivation to start the lessons, seeing that there are other things to do online. Also, the thought of freedom and comfort to be late in classes makes me join the classes when I am still sleepy.

Some also identify the reason with their computer habits. For Doruk (1R62), "attending classes on my computer, which has been my entertainment box so far, is becoming the least productive event of my life." For Miray (Participant 1R62) also, maintaining her attention online is tiresome. She starts "knitting during the classes [because] I feel too sleepy, as if a stallion is sitting on my eyes."

Maintaining attention online is a challenge for the students. And, in order to maintain attention, they are expected to "be self-motivated and self-directed" (Kebritchi, Lipschuetz \& Santiague, 2017, p. 8). In addition to this expectation, studying online at home in isolation with other family members due to the coronavirus outbreak makes it more challenging for them. In a short period of time, they are required to adopt their learning styles and skills to participate in online courses successfully. The students with lower levels of self-directed learning skills (see Lin \& Hsieh 2001, p. 382) and with lower self-efficacy (see Tsai \& Tsai 2003, p. 48) are now expected to perform well online and remove those pandemic-related obstacles at the same time. 


\section{Lack of Interaction}

Online education, for many participants, lacks interaction. Those students repeatedly complain that online classes do not possess an interactional environment. For them, it is one of the most fundamental components of a teaching and learning activity. And, when they are suddenly asked to move online due to the coronavirus outbreak, they find themselves in this unfamiliar virtual environment, expecting the same interactional characteristics that they are used to experiencing in the traditional face-to-face classrooms.

The lack of interaction in virtual classrooms results in three problems. First of all, online education does not provide an authentic classroom atmosphere. For the students, the authentic classroom atmosphere in the classroom involves many interactional features ranging from body language, mimics, chats, and gossips among the classmates to writing on the board, sitting at the desks, taking notes with pen, or walking in the classroom. Supporting this argument, Kuzey (Participant 1R107) stresses the role of social qualities of education in classrooms:

Education is communication, and communication usually requires concreteness. Perhaps there is no big difference between the two cases, but we have realized that over years we are used to the social qualities of education, classroom settings and educational materials.

A similar remark by Azra (Participant 1R119) argues that feeling is a crucial part of classroom life, and how it plays a key role in her success:

I think that the only thing that we have is feeling. It is more emotional [more feeling] to feel the texture of book cover than touch on the screen to turn over the page. As a result, when I take notes with my hands, when I write important topics with coloured pencils, or when I write a fancy note on a book (it does not have to be fancy, it can be just regular note), I feel that I have accomplished more.

Masal (Participant 2R03) describes her frustration with online education with the "wall" metaphor:

The classes are not interactive. No matter how much the teachers and students try [to make it more interactive]. As if the teacher was talking to the wall, and we were watching that wall.

Secondly, according to the participants, online education offers limited opportunities for mixing socially with others. In other words, because virtual classes do not possess the interactional qualities of traditional face-to-face classrooms, there are fewer opportunities for the students to get together and socialize with their classmates online. Those opportunities, for them, can happen in the classrooms, such as laughing at a joke or engaging in a controversial debate, or take place outside the school like drinking a cup of tea in the school cafeteria, visiting toilet during the break, working together in the library, or meeting in a restaurant. In order to emphasize the role of socialization in the university, Miray (Participant 1R109) gives an example:

We would meet and work together with my friends in the library or in the café after the classes. Not only did we study productively, and we were enjoying it, but also we would motivate each other by observing the others work. 
Also, because most of the participants are in their freshman years when this study is conducted, and because due to the pandemic, they are attending online education, they have not had any opportunity to meet their classmates and thus to create any friendship in the university. Pelin (2R01) talks about the lack of new friendship in her class:

This is my first year in this department. Consequently, I haven't met any friend. I don't know anyone. I haven't had any friend [from the department]. This is also a big problem for me. I wish I could go out with my friends, chat, have fun with them, talk about the courses, after the classes. But, right now I haven't met anyone. I haven't socialized at all.

The third problem, according to the students in the study, is that they cannot have any experience about their practical courses with online education. For them, online education does not provide any practical experience. Because they are studying teaching, and because they will become teacher after they graduate, many think that teaching requires practice in authentic settings. Esra (3R44) gives an example:

For example, math is the course that one can understand with texts and visuals. I watched in some Youtube videos that they explain the topics with three dimensional figures. I think this is more effective.

\section{Online Examination}

The last problem with online education is online examination. For many participants in this study, online examinations lack policy to ensure fairness, and thus it maximizes abuse and cheating. Masal (Participant 2R03) gives an example:

There is no regulation. Of course, you [as the instructor] can ask us to turn on our cameras and microphones during the exam. This is an option. But, we didn't have this type of exam this year. And, in a tricky question, it is really really easy to send the correct answer to your friend on WhatsApp.

The same worry is expressed by the university students in the study by Kürtüncü and Kurt (2020, 72). A senior student expresses her worry:

While cheating cannot be prevented in face-to-face examinations, I think the students' efforts will be wasted in online examinations [due to cheating].

\section{Online Education: Suggestions}

In addition to the pros and cons of online education, the participants are asked to provide some suggestions to improve the quality of online education. Their suggestions are discussed in two parts. The first group focus on what the instructors can do to improve the effectiveness of online classes. One of the most frequently stressed proposals in this group is that instructors should first keep their cameras on and then ask students to turn on their cameras and microphones during online classes (see An \& Frick, 2006, pp. 495-496 for a similar suggestion).

From Pelin's (Participant 2R01) point of view, keeping cameras on during online lessons would stimulate a regular classroom environment where the students "can see each other's face." For Sena (2R02), it also creates a connection between the instructor and students: 
[If I were the instructor] I would probably ask my students to turn on their webcams. Not to control their behaviour, but to make a connection with them. To give the message to the students: I am here, how about you?

The other suggestions for the teachers include taking attendance, having short breaks, learning more about the student profiles, understanding their situations and problems, making more quizzes, making use of boards, asking more question and becoming more interactive, motivating the students to ask questions, providing more online resources, holding individual sessions with some students, having online office hours, and using visual resources to make the lessons more attractive for the students. Zekiye (Participant 3R1) gives an idea of what she would do if she were an instructor:

I would share the video, which I record myself talking about the topic, with my students a couple of days earlier. I would ask my students to note down their questions and the points that they don't understand. In the lesson, I would answer their questions and explain those points, and would give them a short assignment or exercise about them.

Like Zekiye, Esen (Participant 3R48) describes what an instructor should do to improve online teaching:

I would give a lot of assignments. But, I would arrange those assignments not to be too much time-consuming. I would create some activities to enjoy the moment, letting them know that this [online education] is different from watching videos on YouTube. I would make them remember that they are still students, letting them know there are more things than those classes that they face. I would organize game tournaments, open reading clubs, and would meet them once every week to talk about a movie. Although this might mean that I have to spend more time for work, I would do anything that I can do to prevent my students from not experiencing student life.

Those suggestions reflect the four roles identified for online instructors: pedagogical, social, managerial, and technical responsibilities (see Berge, 1998). And, the participants' suggestions in this study place the emphasis on the pedagogical and managerial responsibilities of online teachers. The online instructors are expected to perform instructional goals, delivering content and using technology to do so, and to organize and guide their students to learn online better (Tucker \& Neely, 2010, p. 29).

The second group in this section is the suggestions about what the administrators should do. One of the proposals that the participants offer is that the authorities should provide the equal opportunities to all students, including the free internet and affordable computers or tablets. Nilgün (Participant 3R55), for example, thinks that the authorities should "find the students without computer or tablet and should provide them." A similar suggestion by Hakan (3R65) pictures the current situation with the online education in Turkey:

I think the biggest problem is that there are still some students that do not have the internet or the gadget to get connected to online education. Seeing that we are now in the 21st century, I think they [the authorities] should realize that this is not a luxury but a need, and that they should fix this problem.

The second proposal is about creating small classrooms with fewer students. According to some students, this would let the instructors spare more time for each student. Masal (Participant 2R03) supports this proposal with her formulation: "The fewer students in the class, the more interactive the class." As a result, she disagrees with the frequent practice of merging a couple of groups into an online 
class. Another suggestion by Yaşar (Participant 3R02) is about online teaching program, proposing that online applications or programs can be upgraded to be able to send instant notifications to the students when the online lessons start.

\section{Discussion}

This study explored how a group of students in a public university in Turkey made sense of their online teaching and learning activities during the coronavirus outbreak. Between October 2020 and January 2021, the study collected the data from 165 freshman students. 133 participants took part in the first stage, describing their initial experiences with online education in a one-page note, 25 participants talking about those experiences in the semi-structured interviews, 89 responding to the online survey, and 7 sending feedback for the draft report in the last stage. The data from these four sources were presented in four sections: (1) the participant' routines with online education, (2) the benefits and (3) the disadvantages of online education according to their online practices, and (4) the students' suggestions to improve the quality of online learning.

One of the striking findings from the study suggested that it was the coronavirus outbreak that introduced the participants to the virtual teaching and learning environment. Although Turkey has a long history of distance education, the suddent and massive shift to online education due to the pandemic created a "didactic and structured" virtual education facility that lacks the qualities of conventional face-to-face education (Bozkurt et al., 2020, p. 85). And, as Ali (2020) puts forward in his study, "transitioning to online learning at scale is a very difficult and highly complex undertaking for education systems" (p. 21), the students and instructors in the higher education instiutitons in Turkey could not adjust their teaching and learning habits to the new circumstances in this speed of this complex undertaking. To put it another way, the study showed that before the pandemic, few participants had limited previous experience with online education, such as watching online lessons on YouTube or informal video meetings with the instructors on WhatsApp. And, studying online at home in isolation due to the pandemic emerged as an unforeseen, unplanned, and massive shift for them. One of the consequences of this sudden shift caused the participants to mistakenly associate the drawbacks of coronavirus quarantine with the undesirable characteristics of online education. Some participants, for example, viewed online education as a barrier for "campus socialisation" (also discussed by Adnan \& Anwar, 2020, p. 49). However, the lack of interaction, socialization, and isolation was the result of nationwide lockdown due to the coronavirus, not the adverse results of online education. This argument thus provides a research opportunity for further studies to explore how the coronavirus pandemic plays a key role in shaping online education in higher education.

The sudden transition to online education due to the coronavirus outbreak has accelerated the the process of digital transformation in the higher education institutions. The digital transformation has been already expanded massively because of the recent developments in the internet technologies (Kebritchi, Lipschuetz \& Santiague 2017, p. 5). However, when the coronavirus outbreak made the national authorities use online education as the sole solution for continuing teaching and learning activities in the countries, the process of digital transformation speeded up radically. However, this sudden immense transformation process caused some serious problems in the education field. To start with, the students from the undeveloped, remote, and rural areas had limited access to online education due to poor (or no) internet or a lack of internet (see Aristovnik, Keržic, Ravšelj, Tomaževic \& Umek, 2020, p. 8 for a similar finding). Also, because the students had very limited time (the decision for moving to online education was made in two weeks in Turkey), the students had probblems in adopting 
themselves to this new virtual learning environment, and the students had trouble in developing selfdiscipline to maintain their focus online (see Bao, 2020, p. 114). A good illustration of this is the participants' complaint that the virtual classes lack interactional qualities (see Brown \& McCall, 2021, p. 6). Because the pandemic made it impossible for the students to change their learning habits, they had the same expectations for online education. As a result, this argument offers a new research area in the field of online education, exploring how the students and teachers adapted their teaching and learning habits to the online education circumstances in such a short time.

The fundamental advantage of online education that was frequently emphasized by the students in the study was that online education provided safety for the students. The participants in the study believed that studying online at home and in isolation prevented the coronavirus spread. The same argument was supported by the study by Dowd et al. (2020, p. 9697). Their study indicated that the school settings could be a hub of virus transmission. The study by Özdoğan and Berkant (2020, p. 23) supported this argument and reported that one of the benefits of online education was that it minimized the risk of coronavirus spread and kept the students and their parents safe from the virus. In addition to keeping them safe at home, online education also created a convenient teaching and learning environment. Similar to the findings in the studies by Young and Norgard (2006, p. 113) and Coyner and McCann (2004, p. 224), online education offered the students a more efficient, faster and cheaper accessibility for the teaching and learning opportunities. The students in this study, for example, told that watching the video-recorded lesson in the evenings let them focus more on their learning and spare time for other activities. However, this advantage resulted in an indirect consequence: The students lost their independence. To put it another way, when the participants moved back to their parents' houses due to the pandemic, they started losing their early adulthood independence. While they were independent before the coronavirus outbreak (earning and spending their own money, managing their daily routines, and organizing their lives on their own), living with their parents due to the lockdown limited their initial experiences of early adulthood. This surprising finding in the study can be explored more in further studies, focusing especially on how moving back to parent's home plays a significant role in shaping the university students' early adulthood experiences.

In addition to the disadvantage listed in the previous paragraph, there were two main problems with the sudden massive transition to online education in Turkey. The first one was rooted in the lack of resources. Most students had trouble in obtaining a computer for online education. Or, due to the frequent power cuts, some students were left with no choice but to use their mobile connections (see Kürtüncü \& Kurt, 2020, p. 72 for similar findings). The second problem was about the lack of digital literacy among the instructors and students in the higher education institutitons (see Hodges et al., 2020, p. 2). Because the students did not have enough time to get prepared for the basic characteristics of online education, the studens and teachers with no or limited digital literacy experience had trouble in following the courses designed for virtual classes. In addition to these major problems, the study also unraveled some less frequently stressed problems. The study, for example, showed that there was the student with visual impairmen who has a lot of trouble in watching the screen for a long time because after some time it started hurting his eyes. Also, there were seven foreign students in the study. All of those foreign students reported that they had difficulty in following the courses in Turkish. The language of instruction over the internet created a linguistic barrier for them (see Duffy, Gilbert, Kennedy \& Kwong, 2002, p. 78 for the finding in language and online education). These two problems can be explored more in further studies, especially investigating how disability is accounted for in 
online education, or how language plays a key role in shaping the students' online education experiences.

The first limitation of the study was rooted in the sampling technique. The sample, the researcher's undergraduate students in his course, the Sociology of Education, was conveniently and purposefully selected. As a result, the findings of the study could be attributed to this sample group or in same cases to similar groups. Also, the students might have refrained from providing some critical data because the researcher was their instructor, and thus they did not want to risk their identities. Thus, a further study can replicate this work with a larger sample group and check if similar findings can be obtained. The second limitation was the data collection methods. The descriptive data in this study were collected online, using Microsoft Teams, the student emails, and the interviews on Zoom. Collecting data online might obstruct the hidden face of the interactions. To put it another way, because collecting data using the internet could fail to uncover some critical information that might normally be gathered in tradition face-to-face data collection methods such as observation and interviews. Thus, a further study can collect data about the students' experiences with online education using face-to-face methods, focusing especially on the interactions among the students.

\section{References}

Adnan, M., \& Anwar, K. (2020). Online learning amid the COVID-19 pandemic: Students' perspectives. Journal of Pedagogical Sociology and Psychology, 2(1), 45-51.

Ali, W. (2020). Online and remote learning in higher education institutes: A necessity in light of COVID19 pandemic. Higher Education Studies, 10(3), 16-25.

Altun-Ekiz, M. (2020). Beden eğitimi ve spor yüksekokulu öğrencilerinin karantina dönemindeki uzaktan eğitim ile ilgili görüşleri (nitel bir araştırma). Journal of Sport and Recreation Researches, 2(1), 1-13.

An, Y., \& Frick, T. (2006). Student perceptions of asynchronous computer-mediated communication in face-to-face courses. Journal of Computer-Mediated Communication, 11, 485-499.

Anderson-Levitt, K. M. (2006). Ehtnography. In J.L. Green, G. Camilli, \& P.B. Elmore (Eds.), Handbook of complementary methods in education research (pp. 279-295). Washington, DC: American Educational Research Association.

Aristovnik, A., Keržic, D., Ravšelj, D., Tomaževic, N., \& Umek, L. (2020). Impacts of the COVID-19 pandemic on life of higher education students: A global perspective. Sustainability, 12(8438), 134.

Bao, W. (2020). COVID-19 and online teaching in higher education: A case study of Peking University. Human Behavior and Emerging Technologies, 2, 113-115.

Bates, T. (2005). Technology, e-learning and distance education (2nd ed.). London: Routledge.

Bedford, J., Enria D., Giesecke J., Heymann D. L., Ihekweazu C., Kobinger G., ... Wieler, L. H. (2020). COVID-19: towards controlling of a pandemic. The Lancet, 395(10229), 1015-1018.

Berge, Z. L. (1998). Barriers to online teaching in post-secondary institutions: Can policy changes fix it? Online Journal of Distance Learning Administration, 1, 1-12. 
Brown, G., \& McCall, V. (2021). Community, adaptability, and good judgement: Reflections on creating meaningful, sustainable pedagogy in uncertain times. Developing Academic Practice, January, 59.

Bozkurt, A., Jung, I., Xiao, J., Vladimirschi, V., Schuwer, R., Egorov, G., ... Paskevicius, M. (2020). A global outlook to the interruption of education due to COVID-19 pandemic: Navigating in a time of uncertainty and crisis. Asian Journal of Distance Education, 15(1), 1-126.

Coyner, S. C., \& McCann, P. L. (2004). Advantages and challenges of teaching in an electronic environment: The accommodate model. International Journal of Instructional Media, 31(3), 223228.

Crawford, J., Butler-Henderson, K., Rudolph, J., Malkawi, B., Glowatz, M., Burton, ... Lam, S. (2020). COVID-19: 20 countries' higher education intra-period digital pedagogy responses. Journal of Applied Learning \& Teaching, 3(1), 9-28.

Daniel, J. (2020). Education and the COVID-19 pandemic. Prospects, 49, 91-96.

Dhawan, S. (2020). Online learning: A panacea in the time of COVID-19 crisis. Journal of Educational Technology, 49(1), 5-22.

Dowd, J. B., Andriano-Liliana, B., Rotondi, D. M., Valentina, B., Block, P., Xuejie, D., ... Mills, M. C. (2020). Demographic science aids in understanding the spread and fatality rates of COVID-19. Proceedings of the National Academy of Sciences of the United States of America, 117(18), 9696-9698.

Duffy, T., Gilbert, I., Kennedy, D., \& Kwong, P. W. (2020). Comparing distance education and conventional education: Observations from a comparative study of post- registration nurses. ALT-J Research in Learning Technology, 10(1), 70-82.

Erkut, E. (2020). Covid-19 sonrası yükseköğretim. Journal of Higher Education (Turkey), 10(2), 125-133.

Eroğlu, F., \& Kalaycı, N. (2020). Üniversitelerdeki zorunlu ortak derslerden Türk dili dersinin uzaktan ve yüz yüze eğitim uygulamalarının karşılaştırılarak değerlendirilmesi. Ana Dili Egĭtimi Dergisi, 8(3), 1001-1027.

Hodges, C., Moore, S., Lockee, B., Trust, T., \& Bond, A. (2020). The difference between ermergency remote teaching and online learning. Educase Review, March, 1-15.

Karadağ, E., \& Yücel, C. (2020). Yeni tip Koronavirüs pandemisi döneminde üniversitelerde uzaktan eğitim: Lisans öğrencileri kapsamında bir değerlendirme çalışması. Yükseköğretim Dergisi, 10(2), 181-192.

Kebritchi, M., Lipschuetz, A., \& Santiague, L. (2017). Issues and challenges for teaching successful online courses in higher education: A literature review. Journal of Educational Technology Systems, 46(1), 4-29.

Kornbluh, M. (2015). Combatting challenges to establishing trustworthiness in qualitative research. Qualitative Research in Psychology, 12(4), 397-414.

Kozinets, R. V. (2010). Netnography: Doing ethnographic research online. Thousand Oaks, CA: Sage.

Kurnaz, E., \& Serçemeli, M. (2020). COVID-19 pandemi döneminde akademisyenlerin uzaktan eğitim ve uzaktan muhasebe eğitimine yönelik bakış açıları üzerine bir araştırma. International Journal of Social Sciences Academy, 2(3), 262- 288. 
Kürtüncü, M, \& Kurt, A. (2020). Covid-19 pandemisi döneminde hemşirelik öğrencilerinin uzaktan eğitim konusunda yaşadıkları sorunlar. Eurasian Journal of Researches in Social and Economics, 7(5), 66-77.

Li, C., \& Irby, B. (2008). An overview of online education: Attractiveness, benefits, challenges, concerns and recommendations. College Student Journal, 42(2).

Lin, B., \& Hsieh, C. (2001). Web-based teaching and learner control: A research review. Computers \& Education, 37, 377-386.

Marinoni, G., van't Land, H., \& Jensen, T. (2020). The impact of COVID-19 on higher education around the world: IAU global survey report. Paris: International Association of Universities.

Marshall, C, \& Rossman, G. B. (2011). Designing qualitative research (5th ed.). Thousand Oaks, CA: Sage.

McAleer, M. (2020). Prevention is better than the cure: Risk management of COVID-19. Journal of Risk and Financial Management, 13(3), 46.

Miles, M. B., \& Huberman, A. M. (1994). Qualitative data analysis: An expanded sourcebook (2nd ed.). Thousand Oaks, CA: Sage.

Özdoğan, A. Ç., \& Berkant, H. G. (2020). Covid-19 pandemi dönemindeki uzaktan eğitime ilişkin paydaş görüşlerinin incelenmesi. Milli Ĕ̆itim, 49(1), 13-43.

Patton, M. Q. (2002). Qualitative research and evaluation methods (3rd. ed.). Thousand Oaks, CA: Sage.

Saltürk, A., \& Güngör, C. (2020). Üniversite öğrencilerinin gözünden Covid-19 pandemi döneminde uzaktan eğitime geçiş deneyimi. Adıyaman Üniversitesi Sosyal Bilimler Enstitüsü Dergisi, 13(3), 137-174.

Singh, V., \& Thurman, A. (2019). How many ways can we define online learning? A systematic literature review of definitions of online learning (1988-2018). American Journal of Distance Education, 33(4), 289-306.

Swan, K., Shea, P., Fredericksen, E., Pickett, A., Pelz, W., \& Maher, G. (2000). Building knowledge building communities: Consistency, contact and communication in the virtual classroom. Journal of Educational Computing Research, 23(4), 359-383.

Tsai, M., \& Tsai, C. (2003). Information searching strategies in web-based science learning: The role of internet self-efficacy. Innovations in Education and Teaching International, 40(1), 43-50.

Tucker, J. P., \& Neely, P. W. (2010). Unbundling faculty roles in online distance education programs. International Review of Research in Open and Distributed Learning, 11(2), 20-32.

Tuncalp, D., \& Le, P. L. (2014). (Re)Locating boundaries: A systematic review of online ethnography. Journal of Organizational Ethnography, 3(1), 59-79.

Turkish Statistical Institute. (2020). En popüler bebek ismi erkeklerde Yusuf, kızlarda Zeynep oldu. Basin Odası Haberleri 3.

Wang, C., Horby, P. W., Hayden, F. G., \& Gao, G. F. (2020). A novel coronavirus outbreak of global health concern. The Lancet, 395(10223), 470-473.

Yolcu, H. H. (2020). Koronavirüs (Covid-19) pandemi sürecinde sınıf öğretmeni adaylarının uzaktan eğitim deneyimleri. Açıoör̆etim Uygulamaları ve Araștırmaları Dergisi, 6(4), 237-250. 
Young, A., \& Norgard, C. (2006). Assessing the quality of online courses from the students' perspective. Internet and Higher Education, 9, 107-115.

Yuki, K., Fujiogi, M., \& Koutsogiannaki, S. (2020). COVID-19 pathophysiology: A review. Clinical Immunology, 215, 108427.

Zimmerman, J. (2020.) Coronavirus and the great online-learning experiment. Chronicle of Higher Education, March.

\section{Author Contribution Statement}

The author confirms sole responsibility for the following: study conception and design, data collection, analysis and interpretation of results, and manuscript preparation.

\section{Acknowledgements}

I would like to thank my freshman students, who were attending the Sociology of Education course in Fall 2020, and Çisem Görür and Sedat Yakut for their feedback and contributions.

\section{Conflict of Interest}

The author certifies that he has NO affiliations with or involvement in any organization or entity with any financial interest (such as honoraria; educational grants; participation in speakers' bureaus; membership, employment, consultancies, stock ownership, or other equity interest; and expert testimony or patent-licensing arrangements), or non-financial interest (such as personal or professional relationships, affiliations, knowledge or beliefs) in the subject matter or materials discussed in this manuscript.

\section{Ethical Statement}

This study was approved by the Ethics Board at Çanakkale Onsekiz Mart University on December 4, 2020 with approval number 06/16. 


\section{Appendix A}

The instruction for a one-page note on online education

Dear students,

I would like you to write down your experiences with online education. I want you to share your experiences with your online classes (positive, negative, bad, good, surprising, interesting, or funny) with me. Please avoid giving private information such as the name of the instructor, the course, or your friends. Please be honest and sincere. There is no composition rule for your paper. Thank you very much. 


\section{Appendix B}

Interview questions

1. How long have you been attending online education?

1. 1. Did you have any previous experience with online education?

1. 2. Can you talk about it?

1. 2. 1. When?

1. 2. 2. What grade(s)?

1.2.3. What course(s)?

1. 2. 4. What software?

1.2.5. What instrument?

2. What type of technological instruments do you use for online education?

2. 1. Desktop? Laptop? Smart phone? Tablet? Other?

2. 2. Which one do you prefer?

2.3. Why?

2. 4. What problems have you had with it?

3. How is your internet service (that you use for online education)?

3. 1. Broadband connection or mobile? Or other?

3. 2. How is the speed?

3. 3. How is the quality?

3. 4. Any cut-off?

4. Where do you get connected to the internet?

4. 1. Do you have your own room?

4. 2. If not, where?

4. 3. Any problem with sharing your room?

4. 4. Siblings? Relatives?

5. What software do you use for online education?

5. 1. If you use more than one, can you compare them?

5. 2. What problems have you had with the software?

6 . What are the advantages of online education?

6. 1. What do you like about online education?

7. What are the surprising (or strange, or unfamiliar) parts of online education?

7.1. What makes you surprised in online education?

8 What are the disadvantages (or the parts to be improved) in online education?

9. When you compare online education with tradition face-to-face education:

9. 1. What are the cons of tradition education? 
9. 2. What are the cons of online education?

9. 3. What are the pros of tradition education?

9. 4. What are the pros of online education?

10. What should be done to improve online education?

10. 1 . What are your suggestions?

10. 2. For the instructors?

10. 3. For your classmates?

10. 4. For the software?

10. 5. For the administrator?

11. If you were an instructor using online education, what would you do (or not do9?

12. What else would you like to add? 


\section{Appendix C}

Survey Questions

(1) What is your gender?

(2) How old are you?

(3) Where do you live now? City, town, village?

(4) How long have you been attending online education?

(5) In what grades or schools have you attended online education?

(6) Where do you get connected online? Your own room? A shared place?

(7) What technological instruments do you use for online education?

(8) What programs or applications do you use?

(9) What do you do during online classes? Methods? Materials? Techniques?

(10) What are the pros of online education?

(11) What are the cons of online education?

(12) How do you keep in touch with your friends?

(13) How do you contact your instructors?

(14) How do you solve the problems with online education?

(15) What would you do (or not do) if you were an instructor using online education?

(16) What would you suggest to improve online education? 